\title{
On Double Narration in Wuthering Heights
}

*Mr. Omar Ezzaoua

1. Université Ibn Tofail, Morocco Email: omar.ezzaoua@gmail.com

\begin{abstract}
Emily Bronte's Wuthering Heights is characterized by the narrative mechanisms and techniques it employs. Building on its structure, the novel is obviously rich in its underlying elements that are worth examining. One of these elements is the choice of multiple narrators and the complex organization of narrative time. This theoretical framework deals mainly with narration and narrative techniques as approached by structuralist narratology. As an approach that examines narration and its major hybrids, narratology delves into a structural study of Wuthering Heights allowing for a deep examination of the underlying narrative elements in the novel. Having said that, it is believed that the study of narratology is pertaining in the sense that it sheds light on how the narrative structure of the novel puts into question the status of the narrators as reliable sources. This structure also mystifies the story giving the reader a chance to decipher the intent of the characters involved as both narrators and characters. Without taking such structure into account, the readers are missing some key elements in understanding and interpreting the stories told by the narrators.
\end{abstract}

KEY WORDS:Wuthering Heights, Narrators, Narratology. Structuralism

\section{Introduction}

Important studies on narration and narrative techniques date back to Aristotle's works. However, the accumulation of literature and literary criticism during the 20th century has proved that Aristotle's Poetics were no longer sufficient to account for the underlying variations in literature and narrative. This situation has paved the way to a reconsideration of prior studies on arts and literature in the light of the new challenges. The idea found its way in the work of the French philosopher Tzvetan Todorov in his Grammaire du Décaméron (1969). Todorov maintains that there should be a focus on structural properties of narrative as a univers de representations. He advocates a general theory that could be applied to all domains of narrative, and in fact for a hypothetical "science that does not exist yet; let's call it Narratology, or science of narrative."(Todorov, 1969, p 10). Rather than focusing on what a narrative is about, Todorov stresses the importance of dwelling on the structural elements of narration.

To this end, he maintains that there is an underlying relationship between narrative and syntax; A relationship between the paradigmatic and syntagmatic components of the story. Todorov proposes a form of analysis that focuses on the syntax of narrative. He stresses that there is an important difference between what he calls 'histoire' ( narrative signified) and 'discours' ( the narrative signifier). This syntagmatic "analysis of narrative permits us to isolate formal units which present striking analogies with the parts of speech: proper noun, verb, adjective" (Todorov, 1969,p. 113).
Todorov argues that we may "understand narrative better if we know that the character is a noun, the action a verb" (Todorov, 1969,119). to make his position clear, Todorov conducts a study on The Camerouns in which he attempted to concreticize and apply narratological model. This study's main aim was to decipher the homologous relationship between narrative and grammar through analogizing the syntactic components with story components.

Equally important, the contribution of the Russian philosopher, Vladimir Propp has been of great significance in shaping a structural approach toward literature and art. Building on the Russian formalist studies of local folktales' structures, Propp extends this approach to narratology by devising a typology, and division of the smallest narrative units that are common in the Russian folktales, and ultimately, comes to the conclusion that these folktales includes thirty-one generic narratemes. Additionally, Vladimir Propp distinguishes eight character types in his work; heroes vs. sought-for person, father/dispatcher vs. hero, helper/provider vs. villain/false hero "dramatis personae ".(Propp, 1928)

The influence of Propp's Morphology of Folktales was also clear in the work of Julien Greimas (1983) (1989). Propp's discoveries were the standpoint upon which Gerimas (1983) established his theory of narrative. More importantly, Greimas 's (1983) theory of narrative took a holistic dimension in an attempt to apply a typology to all sorts of narratives not only folktales or myths. 
Greimas introduced narrative actants or actional roles(1983,1966 p. 178); an actants is the action performed by a character. These actants are classified into six categories ; the actants comprise "subject vs. object, " "sender vs. receiver, " and "helper vs. opponent.

The structural investigation of narratives tells something important about the universality of human experience regardless of their background. The common artistic manifestations show that peoples share the same understanding of the world. In fact, It is this very revealing point that narratology tries to evoke.

\section{Gerald prince states :}

to speak more generally, narratology does have crucial implications for our self-understanding. To study the nature of narratives, to examine how and why it is that we can construct them, memorize them, paraphrase them, summarize and expand them, or organize them in terms of such categories as plot, narrator, narratee, and character is to study one of the fundamental ways - and a singularly human one at that-in which we make sense. (1990, p. 1-2)

Interestingly, this approach, thanks to (Barthes, 1966) Bremon (1973), and Greimas, has extended to include not only literature but other artistic forms. They transcend the common sensical nature of narrative to include other forms of arts in which narrative can be applicable as a medium of conveying a message. In this respect, Bremond (1973), states that narrative can be realized in theatre, ballet, and film. Mixing genres $(\rightarrow$ Narration in Poetry and Drama) and media, Barthes expands the list:

Among the vehicles of narrative are articulated language, whether oral or written, pictures, still or moving, gestures, and an ordered mixture of all those substances; narrative is present in myth, legend, fables, tales, short stories, epics, history, tragedy, drame [suspense drama], comedy, pantomime, paintings (in Santa Ursula by Carpaccio, for instance), stained-glass windows, movies, local news, conversation. Moreover, in this infinite variety of forms, it is present at all times, in all places, in all societies.(p.237)

For Barthes, Narration is as old as human's existence, it has been present whenever and wherever humans exist. This tradition was embedded in different forms of art .However, my focus will be more on narrative in literature, and more specifically in fiction.

Barthes also obeys the injunction from Le $\square$ vi-Strauss (1973) to "dechronologize " narrative in a manner not dissimilar to the "synchronic" reworking of the Oedipus myth. "Both language and narrative, "Barthes asserts, "know only a semiotic time, 'true' time being a 'realist,' referential illusion.
" However, the level of narration in Barthes's essay marked a significant departure from the fathers of narratology. Instead of dealing with "content, " "raw story matter, " or the arrangement of fabula alone, narration included contemplation of what are now standard narratological focuses, such as the role of the narrator and point of view.

Due to its multifaceted nature, narratology has faced many obstacles in delimiting its areas of studies. In this regard, Jackson Barry writes, "One of the most striking aspects of narratology is the way it tends to provide several different terms for the same phenomenon, each one the creation of a different 'school"'(1990, 240). This approach toward narratology generated different schools of thought that deal with the same term from different perspectives. Additionally, the studies of narratology gave birth to an unlimited number of concepts related to the term. This is in fact a major problems that might be faced while attempting to delve into research on narratology. An even, naratologists seem to approach narratology from different vantages: "If Aristotle is mainly focused on theme, Propp on plot, ... Genette on narration [and] Barthes on the reader..." (Barry:1990, p 240).

\section{Narrator Status}

In any literary work, it is confusing to tell the narrator from the author. Barthes points out that (commentators have studied the "author" of a novel without being too concerned incidentally whether he is really the "narrator") $(1966,260)$. Narrators are so distinct from authors. Needless to say, in the case of a first person narrator an author can create different narrators in different works, hence we cannot claim that they all represent the author. Similarly, in an autobiographical work, we cannot claim that the narrator and the author are the same person. A work of literature are above all a work of fiction and to mistake the author for the narrator is misleading. Likewise, an important question seems to come into play.

Interestingly, in work of fiction such as Wuthering Heights, we , as readers, are confronted with more than a narrator. So, with whom are we going to identify the narrator? this proves that a narrator is utterly distinct from the writer. Writers create narrator with different degrees of presence, distances, reliability, and awareness.

The narrator is the voice through which the story is told. This voice could be first person, meaning the one telling the story using the first pronouns "I" or "we" and the reader sees things from the eyes of this "I" narrator. The voice or narrator could be a second person and uses the word "you" in telling the story. This is not very commonly used as it gets tiresome. 
The one speaking sounds like he/she is commanding the reader to do this, to hear that, to see this and that. The voice or narrator could be a third person, somebody who sees things from a distance. This third person could be limited or omniscient. Limited means he/she knows only the thoughts of one character or no character but only sees actions and hears sounds.

The omniscient narrator sees all and knows all thoughts, whereas, the writer is the one who creates the story and the narrator as well. According to Prince, " a distinction is made among the first person ("I", for example ), the second person ('you') and the third person ( 'he"). The first person is defined as the one who speaks, the second as the one who is spoken to, and the third person as the being or the object that is spoken about(1982, p. 4).As far as the first person narrator is concerned, an "I" representing the narrator may or may not appear". It may not appear because even with the omission of the I, the meaning does not change because " we know nothing explicit about the narrator...except that he is recounting events in which he takes part" ; there is not opinion expressed here, instead, there is only a description of what's going on. This distinction between the first and the second person narration is also dealt with by Wayne $\mathrm{C}$. Booth in The Rhetoric of Fiction. Booth states that "To say that a story is told in the first or the third person will tell us nothing of importance unless we become more precise and describe how the particular qualities of the narrators relate to specific effects"(1961, p. 150). To make his position clear, Booth refers to some cases in which there are no clear cut distinctions between the position of the first person and the third person in narration.

Sometimes, a first person narrator refers in his narrative to the writing process or experience of the story. The idea of a self-conscious narrator or a narrator's awareness of his presence as a writer in the story is referred to in Booth's The rhetoric of Fiction. Booth states that a self-conscious narrator is "

aware that he is narrating "P?, he is aware of himself as a writer as opposed to those narrators "who seem unaware that they are writing, thinking, speaking, or 'reflecting' a literary work (Camus's The Stranger, Lardner's "Haircut," Bellow's Th Victim)" (Booth $(1961,155)$ In the first case, the author seems to be aware of himself or herself as more than a narrator, but as a writer as well so as to be able to connect with the readers: he explicitly reveals to the readers that the story is written by him , and comments within the text on the story telling process, in-order link friction and reality.
Moving beyond the personal characteristics of the narrator, let us see how to gauge her/his role as the teller of the tale. Is the narrator reliable or unreliable? Is the narrator telling you everything $\mathrm{s} /$ he knows? What limits does the narrator have, in terms of what s/he can perceive? We'll read some stories with crazy narrators, or stupid, a drunk narrators, or narrators who just don't seem to know what they're talking about for one reason or another.

However, This does not mean that there is a tendency to prefer a reliable narrator as a storyteller: "a reliable narrator is not necessarily one that [the reader] agrees with: after all however honest and trustworthy he may be portrayed as, I may find his values repugnant and his conclusions stupid. Conversely I may find the attitudes of an unreliable narrator very attractive" ( Prince , 1982, p. 8)

Equally important, In his Time and Narrative, Paul Ricoeur, argues that "The case of the unreliable narrator is particularly interesting from the point of view of an appeal to the reader's freedom and responsibility"no page. To put it another why, the readers, Ricoeur maintains, are guaranteed more freedom and excitement if they have access to the story through an unreliable narrator. The readers are always predicting the upcoming events, hence, the less reliable a narrator is the more exciting the story gets. This point is also shared by David Lodge says in The Art of Fiction who states that:

Unreliable Narrators are invariably invented characters who are part of the stories they tell...Even a character-narrator cannot be a hundred per cent unreliable. If everything he or she says is palpably false, that only tells us what we know already, namely that a novel is a work of fiction. There must be some possibility of discriminating between truth and falsehood within the imagined world of the novel, as there is in the real world, for the story to engage our interest. (1992, p.154).

We shall note here that David lodge uses the term character to speak about the unreliable narrator. Following this, we are dealing here with a First-person narrator who is both a narrator and a character. We can never know if they are being honest characters or not telling the truth for one reason or another. A narrator may be a reserved character who does not like to reveal everything, who does his best to look good in his narration. The case of a third person narrator is different: we cannot claim that this types of narrators is unreliable unless the story contains contradictory elements that prove so.

The other distinction that can be made regarding the narrator' voice is the variations of Distance. This distance may be from the implied author (the "author's second self), the characters, and from the readers. This degree may change in the course of events. In any "reading experience there is an implied dialogue among author, narrator, the other characters, and the reader. 
Each of the four can range, in relation to each of the others, from identification to complete opposition, on any axis of value, moral, intellectual, aesthetic, and even physical" (Booth 1961, p. 155).

For instance, modern authors have "experimented with unreliable narrators whose characteristics change in the course of their works they narrate" (Booth 1961,. 156) . This change may be radical or partial, and in both cases the narrator would hold a different view from the characters, the readers, and from the implied author. Equally significant, Prince states that "a narrator may be at a greater or lesser distance from the the events narrated, from the characters presented andor from his narrate". This distance may be "temporal" "physical" , "intellectual" or emotional .Both Gerard prince and Booth agree on the fact that these aforementioned variations in distance do change in the course of the events in a story. In Modern literature, there are many instances in which the narrator gets closer or distant from his other self as a character This situation of distance shift is also apparent in Wuthering Heights as Mr. Lockwood 's opinion toward Heathcliff has changed in the course if events. This idea will be more elaborated in the following practical parts.

When a story is devised, the writer picks among many technical choices a way of producing a particular result in the story's verbal representation. In this way, the narrative employs verbal distancing to forge a narrative mood that dominates "the regulation of narrative information" provided to the reader (Genette 1980, p. 41). Genette makes a distinction between diegesis (telling) and mimesis (showing) to gauges the narrator's degree of involvement. However, Gennette implies, in any work of fiction, telling and showing are two faces of the same coin. They both means the same thing, and if the writer choses one over the other it is just a technical choice. In his Narrative Discourse,

Gerard Genette attempts to assess the distance between the narrator and the story so as to determine the degree of precision in a narrative and the accuracy of the account. So, Whether the text is a narrative of events or a narrative of speeches, there are four types of discourse: each demonstrating progressively greater distance taken by the narrator with respect to the text (1980, p. 171-172):

1. Narratized speech: The character's words and actions are integrated into the narration, and are treated like any other event .In hid regard, the narrator merely maintains the content of the speech without preserving the real words. In this kind of narration, there language of the narrator is dominant while the language of the speaker is silenced.

Example: I informed my mother of my decision to marry Alberine.
2. Transposed speech, indirect style: The character's words or actions are reported by the narrator, who presents them with his interpretation. Thus this speech is not sufficient to guarantee the character's real speech.

Example: I told my mother that I absolutely had to marry Albertine.

3. Transposed speech, free indirect style: The character's words or actions are reported by the narrator, but without using a subordinating conjunction. This speech is a mixture of the narrator's words and the speaker's words. This kind of speech is relatively more acceptable in reliability than he above-

\section{Genette's focalization}

We have seen that the narrator plays the role of the verbal transmitter of events in the story. As in the case of the heterodiegetic, a narrator can relate the events from an outside position( an omniscient narrator); a god like figure who is in control of every part and bit in the story. Yet, this is not always the case even with the presence of a third person narrator. A narrator may adopt the point of view of a character who may happen to know more than him. Implicitly, this is done in order to add more suspense to the story. What is left unsaid makes the reader more involved in the story. This can be revealed by the end of the story or remains unknown. This approach toward narrative perspective has been referred to by Genette( 1980) as Focalization, "It is defined by Genette as "a restriction imposed on the information provided by a narrator about his characters. His well-known triadic typology (zero, internal, and external) is based on a diminishing de- gree of access to the psychology of the characters" (William F. Edmiston 1989 ,p 729)

To put it clearly, Genette pointed out that the term point of view implies a mismatch between voice and the mood, between who speaks and who sees. Therefore, it would be useful to come out with a rubric that accounts for this confusion, hence, the term focalization. Genette opposes the classical calcification.so instead of that dichotomy of narrator versus the character. Genettes combines the two:

It is certainly legitimate to envisage a typology of "narrative situations" that would take into account the data of both mood and voice; what is not legitimate is to present such a classification under the single category of "point of view," or to draw up a list where the two determinations compete with each other on the basis of an obvious confusion.( 1980, p.188-89).

Gnette's focalization came to account for this relationship between the narrator and the character from a different vantage. Additionally, focalization purports To depict the distinction between narrative voice (who speaks?) and perspective (who sees or perceives?). 
The term perspective as seen earlier implies both narrative voice and perspective. Hence, it could not establish a clear cut separation between the two angles. This is done, Genette argues, in order to " avoid the too specifically visual connotations of the terms vision, field, and point of view" (1970, p. 189). This means that examining the point of view should not be limited to the visual sides.

Genette's focus has been mainly on third person narrators, however, Edmiston argues "little attention has been paid to the problem of focalization in texts in which narrator and character are the same individual" 730.Building on Genette's concept of Focalization, Edmiston attempts to shed light on focalization from the vantage of the first person narrator.

As has already been stated, there are many novels in which the narrator is the protagonist himself. In this case, the narrator does not stick only to what the character knows, but he transcends that to include important details about his life. For example, the narrator may tell us about his childhood, and at that very moment in his life he is less knowledgeable than he is as a mature narrator. Equally important, in the case of external focalization, the narrator says less than the character knows. In autobiographical fiction, this would seem to hold true only toward other characters and not toward

the narrator's younger self. As far as zero focalization is concerned, a first person narrator according to Edmiston can never be omniscience. Unlike a third person narrator, the first person one has to justify his knowledge of every details he provides us with: "the narrator knows more than the character, but his knowledge is not boundless" (1989,p. 731). Finally, accounting for internal focalization seems a bit complicated; it is true that, Edmiston argues, a first person narrator knows less than any character, he can never have access to their inner thoughts but this would never be the case in autobiographical fiction where the narrator implicitly knows more than himself as a character. Following this logic, a restriction of focalization does not apply to the whole story. In other words, focalization might be gradually changing in the course of the events.

\section{Narrative Time and Order}

Important is the question of time in any work of fiction. Time can be dealt with from two angles. There is the time of a narrative, and the time of the story. The latter refers to the actual events that are taking place. The narrative is what we , as readers, have been exposed to, it is how this story reaches us. The nature of both categories stipulates a clear cut distinction. To put it clearly, narrative time follows certain sequence. In a novel, events are taking place consecutively ,whereas, in narrative two events cannot take place at the same time.so, "There is the time of the thing told and the time of the narrative (the time of the signified and the time of the signifier)" Genette.
Moreover, it is impossible, according to Genette, for the story time and narrative time to occupy the same space. It is this very fact that affects the organizational order of narrative. The chronology and the space occupied by a narrative as opposed to that of the story give us some hints about the structural and the underlying elements of a novel.

One of the basic elements in narrative time analyzed by Gerard Genette is the concept of order. Order is the relation between the actual chronological organization of events in the story and their arrangement in the narrative. For example, detective novels often begin with a murder that has to be solved. The events preceding the crime, along with the facts leading to the killer, are presented afterwards. The order in which the events actually occurred does not match the order in which they are presented in the narrative. This mixing of temporal order yields a more gripping, complex plot.

Building on the distinction between narrative time and story time, Genette examines how the two notions of time overlap. The chronological order is not always respected in narratives, thus, a narrator can relate the events out of order. The events in narration does not necessarily respect the chronological sequencing. As a case in the point, detective movies usually starts with the end of the story. Then, we are lagging behind in time to see how an incident has taken place.

Genette uses the terms analepsis and prolepsis to account for the distortion in chronological order. As Genette pinpoints, Analepsis in narration refers to recounting an event that happened earlier than the time of the main story. On the contrary, prolepsis refers to the narrator's recounting of events that will occur after the end of the main story. The term anachrony comprises both terms; it includes a reference to the past or the future. Moreover, Genettes mentions two factors that characterizes an anachrony be it analepsis or prolepsis. These two factors are reach and extent:

An anachrony can reach into the past or the future, either more or less far from the "present" moment (that is, from the moment in the story when the narrative was interrupted to make room for the anachrony): this temporal distance we will name the anachrony's reach. The anachrony itself can also cover a duration of story that is more or less long: we will call this its extent" (1980, p.48).

Anachronies are very important in narrative and they play an important role. Needless to say, the distortion of natural order in narrative may partially occur because of what we have mentioned before: the mismatch between the narrative time and the story time. However, this does not mean that this is the only reason. An anachrony plays some important functions in the narration.

An analepses may take an explanatory role that purports to enlighten the reader about the physical or psychological development of characters by having access to his or her past . 
Equally important, a prolepses in a narrative may aim at arousing the reader's suspense by revealing facts that boost the reader's suspense and anticipation of the story end.

Story time is gauged in years, days, or hours which is not the case in narrative time. The latter operate within a text, hence, its temporality is determined via the textual space it occupies. According to Genette the variations in speed or anisochronies are unavoidable because a narrative where story time would be equal to discourse time is impossible (Genette, 1980 , p. 88). To account for this fact, Genette presents four types of narrative movements : summary, pause, ellipsis and scene (Genette, 1980 ,95). Summary is the concise reformation of a long period of time into a short period in narration (Genette, 1980 96). In this regard, if we compare the story time to discourse time, we will come out to the conclusion that the latter occupies more space than the former: the real story is lasts more than what has been summarized and recounted. But the measurement of time in a story does not hold true in some cases. When a narrator describes a setting, as in the case of Lockwood's description of Wuthering Heights, the chronological order of time if interrupted giving us another dimension of narrative time's ambiguity.

This is what Genette referred to as a pause( Genette, 1980,95$)$. in this case, narrative time seems to occupy more space than story time. Genette emphasizes the importance of descriptive passages that usually mark a pause. Furthermore, there are many instances in narrative where a long period of time is not summarized by omitted instead. For one reason or another, the author chooses to do without it. According to Genette, this ellipsis occurs when a particular temporal period of story is omitted in the narrative (Genette, 1980 ,106). Genette distinguishes two types of ellipsis according to the temporal indications: definite ellipsis and indefinite ellipsis ( two years later etc..)(Genette, 1980,106$)$.

The latter refers to a certain period of time indicated by phrases of time. Indefinite ellipsis is does not precise the exact time ('many years' or 'long years') (Genette, 1980, p. 106). In the case of ellipsis, the story time execs the narrative time simply because parts of the story are not mentioned. The last type of narrative movement presented by Genette is scene which mostly appears as conversations or dialogues. The narrator mentioned the same words uttered by the characters in the story. Therefore, narrative time and story time in the case of scenes are equal. They occupy the same duration.

\section{Narration in Wuthering Heights}

Wuthering Heights comprises different characters manifesting different and mostly conflicting motives and ambitions. They come from different backgrounds each with his or her own history.

The characterization, the settings, the themes as well as other constituents of the book establish a threshold for the readers to immerse into the novel.

The narrative study of the novel raises the important questions of what is the use such a given structure ? Or to put it differently, can the story do without the given narrative structure ? If so what additional effect does the novel's structure have ? Emily Bronte consciously or unconsciously deployed some narrative techniques making of the story a collection of fragmented memories. However, since a structuralist approach towards narration stipulates " The Death of The Author" or a clear cut with the author' identity ,the analysis of narration in Wuthering Heights will be based on this fact.

This position is based on the premise that many writers have produced many books, yet each of their contributions differ partially or completely. Hence, to state that the writer of a series of books approach his works similarly does not make sense. Earnest Hemingway in The old man and the Sea is not the Hemingway in Farewell to Arms and so on and so forth. Equally important, Emily Bronte the poet is not the same as Emily Bronte the novelist. Here comes the concept of the " implied author" by Wayne c Booth in his book The Rhetoric of Fiction ( 1961).

An implied author operates as opposed to the real author or the actual writer. Equally important, an implied reader is the one who is able to decipher the code of a written text. On the other hand, the actual reader sees only what is on the surface level of a text. This distinction is of paramount importance in pinpointing the relationship between the narrator and the narrate. To this end, Wuthering Heights should be dealt with an isolated case of its own.

My thesis is based on the premise that the use of double narration is not accidental, it is a part of the structural organization of the text, it aims at adding suspense to the story. To put it in order way, adopting such technique is a part of the thematic building of story. My analysis of the story is based upon the studies that has been dealt with in the theoretical part. In the first part, an analysis of the narrators' role in Wuthering Heights would be done in the light of their structural and thematic position and function in the story. This will be done in compliance with some works of structuralists. In other word, the main narrators, Mr. Lockwood and Nelly Dean, will be studied through a focus on their presence as narrators and characters. 
Equally important, the second part purports to decipher the chronological strata of narration in the story. That is to say, an analysis of the narrative time and story time will be presented through a reference to Genette's analysis of order :anachronous (analpses and prolepses). For more clarification, these two terms will be discarded and replaced consecutively by flashbacks and flashforwards. The analysis of narrative time aims at pinpointing the chronological order upon which the story is built. Also, it is done in order to depict the narrative position of the narrators regarding their complementary role.

This part questions the efficiency of the choice of such a narrative order given the role of the two narrators. It should be noted that part one and part two do not operate in isolation, but they complement each other. Under the same heading of narrative time and along with the analysis of narrative order, the narratological model of duration as presented by Genette will be applied on the novel. The third part of this paper deals with the Wuthering Heights as a novel that comprises two stories.

The first story of Mr. Lockwood's arrival to Wuthering Heights , and the second story related by Nelly Dean to Lockwood. In this paper we will see how the framing narrative affects the story, how the narrative techniques adopted in the novel produced a mystifying story that involves the reader. It is an attempt to delve into a structural study of narration in Wuthering Heights highlighting some structural elements without which the novel may not gain such success.

\section{Lockwood and Nelly's structural and thematic positions}

The main narrators in Wuthering Heights are $\mathrm{Mr}$. Lockwood and Nelly Dean. They are both present as first person narrators. In other words, Along with their telling of the story, they are characters in these stories. There are instances in which neither of them is present. In this case, They bridge the gap in narration with either reports from other characters or letters. The two narrators are present structurally and thematically in the novel. If we take it for granted that Wuthering Heights is basically the story of the inhabitants of the Heights, Nelly Deans seems more present as an active character than Lockwood. Conversely, if we consider that Wuthering Heights comprises two stories Lockwood is also present thematically in the novel.

Mr. Lockwood opens the narration following his arrival to Wuthering Heights. He introduces the narration through presenting the general context of the setting from the point of view of an outsider. He is situated in the story as a stranger in a "A perfect misanthropist's Heaven" (Bronte, 2). He stimulates the reader to progress in the reading of the novel. On the other hand, Nelly Dean, the second narrator, is more knowlagable than him because she is almost a member of the family. Following this, Both narrators are dramatized narrator( in Wayne Booth's term), and a homodiegetic narrator (in Genette's term).
The two characteristics depict them as being both narrators and characters as opposed consecutively to an undramatized or a heterodiegetic narrator. Mr Lockwood is present in the story, he interacts with Heathcliff, Nelly, and the young Cathy. However, compared to Nelly Dean, Mr Lockwood is not fully dramatized. He is a character with almost no history except what we can induce from his gentile manners, language, and some minute hints at his past. For instance, He uses an educated literary language marked by detailed factual description and perceptive observation and comment, both on situation and character. An example of this is his description of Hareton :

Meanwhile, the young man had slung onto his person a decidedly shabby upper garment, and, erecting himself before the blaze, looked down on me from the corner of his eyes, for all the world as if there was some mortal feud unavenged still between us. I began to doubt whether he was a servant or not... his bearing was free, almost haughty and he showed none of a domestic's assiduity in attending to the lady of the house.(Bronte, 16)

Mr. Lockwood's description of Hareton is marked by the use of an educated style: " feud" "decidedly" " from the corner of his eyes"etc. This linguistic can only be devised by a person who is aquatinted with reading and writing. The description of Hareton's look " from the corner of his eyes" with the " mortal feud unmanaged" visualizes and dramatizes in a way that makes us believe those two men must have known each other. Once again, this style attracts the reader's attention to nature of this character named Hareton. Yet, these signs are not sufficient to describe who really Lockwood is. An educated stranger visiting a place for some reason or another is all that we as readers can infer from the story lines. After all, It seems useless to dwell on the background of a character whose function is merely to exteriorize the curiosity of any reader.

This story is the central part upon which narration is built, and all the other stories revolve directly or indirectly upon it. Lockwood confines himself merely to observing and commenting on what he sees, He is a mere "observer" (Booth, 1961, p. 153). In other words, Lockwood is a narrator who does not produce some measurable effect on the course of the events. Throughout the novel, he describes and comments. His presence in the events is not as important as the other characters' or . The case of Nelly Dean is different.

She possesses the qualities of " a narrator agent" . Narrator agents, according to Booth, are the ones " "who produce some measurable effect on the course of events" (Booth, 1961, p. 154). Nelly is a narrator agent for two reasons. First of all, she considers herself a part and parcel of the Earnshaws family.

The story of Wuthering Heights is a story of a family, and since each member constitutes a part of that intertwined chain, Nelly Dean is no exception. She associates herself with the Heights. 
Her childhood is not referred to in the story, but she tends to focus more on her life in the house "I was almost always at Wuthering Heights; because my mother had nursed $\mathrm{Mr}$. Hindley Earnshaw, that was Hareton's father, and I got used to playing with the children: I ran errands too... (Bronte, p. 44). Equally important, Nelly Dean serves as a mother like figure for the younger characters. Most of the characters, especially the younger inhabitants of Wuthering Heights seem to trust her, divulges their secrets to her, and most importantly ask her for advice. When Edgar Linton has proposed to Catherine, she resorts to Nelly to tell her about the proposal and ask her for advice. Catherine's choice for Nelly is not accidental. She knows that Nelly knows about her, and understands her deep and complex attachment to her beloved, Heathcliff. She has been observing them more than any other person in the Heights:

Nelly would you keep a secret for me?" she pursued, kneeling down by me and lifting her winsome eyes to my face with that sort of look which turns off bad temper, even when one has all the right in the world to indulge it.

"Is it worth keeping?" I inquired, less sulkily.

"Yes, and it worries me, and I must let it out! I want to know what I should do. Today, Edgar Linton has asked me to marry him, and I've given him an answer. Now, before I tell you whether it was a consent or denial, you tell me which it ought to have been. (Bronte, p. 77)

This extract foreshadows the place Nelly occupies an important woman among the family. Catherine seeks Nelly's advice concerning Edgar Linton's marriage proposal. She knows that Nelly understands her motives, she knows that she understands her love for Heathcliff. This, actually, proves the nature of the relationship between Nelly, Catherine, Heathcliff and other members. Additionally, Mrs. Dean is also present as a mediator between Wuthering Heights - the place of wildness and Trushcross Grange - refined society.

She manages to bridge the gap between the Lintons and the Earnshaws, also she manage to gain the confidence of the Lintons as well. To put it clearly, Nelly Dean is not misguided concerning her being a member of the family, the others as well take this fact for granted, they do not treat her as a marginal character, but as a wise woman whose voice is heard in times of troubles. The Lintons also consider Nelly a member of their family. Isabella confirms this when she states that she " must write to somebody, and the only choice left ... is you [Nelly] "(Bronte, p. 217).

Later on she continues "Inform Edgar that I'd give the world to see his face again - that my heart returned to Thrushcross Grange in twenty-four hours after I left it, and is there at this moment, full of warm feelings for him, and Catherine! (Bronte, p. 245).
Nelly also manages " to carry a letter from him [ Heathcliff]to my mistress[ Catherine]; and should she consent, I promised to let him have intelligence of Linton's next absence from home, when he might come, and get in as he was able: I wouldn't be there, and my fellow-servants should be equally out of the way."( Bronte 247). Heathcliff manages to convince Nelly to help him meet Catherine. This is not done out of disrespect for the Lintons, but the insistence of Heathcliff pushes her to obey. She knows that she takes the wrong decision, " she fears it was wrong". If Nelly succeeds in gaining the friendship and respect of most of the inhabitants of Wuthering Heights and Trushcross Grange, it is due to her wise, understanding and kind character.

structurally, Nelly Dean is the most suitable character for narration. This leads us to ask the inevitable question of whether Nelly Dean thematic function qualifies her to take the biggest share in narration or the other way around. In other words, is it her structural role as a narrative technique which allows her to be positioned as the good woman whom everybody resorts to in times of crisis?

Meaning her creator makes her such a flexible character in order to be present in different context as an eyewitness. When Lockwood says "I'll continue it in her own words, only a little condensed. She is, on the whole, a very fair narrator, and I don't think I could improve her style. (Bronte, 249)" we have the impression that he is echoing the words of the writer or more specifically " the implied author" who gradually transfers narration to Nelly.

The diminished degree of distance between Nelly and other characters is the second factor that manifests her being a narrator agent .As a character in the novel, she takes different positions regarding other characters. The distance between her and other characters changes over the time, she is getting closer and closer to other people .In dealing with the question of distance between the narrators and other components of the story, Booth states that "The narrator also may be more or less distant from the characters in the story he tells. He may differ morally, intellectually, and temporally .... morally and intellectually ... morally and emotionally" (961, p. 156).

Mrs. Dean regrets the way she misjudges Heathcliff upon his first arrival, a distance is marked between Nelly's narrating-I and her experiencing-I. Nelly's initial opinion of Heathcliff is negative. Her opinion of him is the same as just about everyone else's. She sees him as a bad person who steals and misbehaves. Then, when Catherine shifts her focus to the Lintons, and Heathcliff gets pushed further and further away from her, Nelly sides with him. The degree of distance marked in these two periods changes. Nelly Dean gets closer to Heathcliff who is discriminated against. More importantly, Nelly gets less distant to her second self as a character. 
Even with Heathcliff's devilish behaviors toward his wife ,Isabella, Nelly cannot help but defends Heathcliff. In doing so, Nelly plays a mediatory role between different characters in an attempt to get peace restored. Regardless of her opinion on Heathcliff, she does her best to defend Heathcliff whenever he is being offended. To make it clear, Nelly keeps her judgements on Heathcliff for herself, or when she is face to face with him. Her judgements are temporal, yet they are contextual. When Isabella describes Heathcliff as inhumane, Nelly replies "'Hush, hush! He's a human being,' I said. 'Be more charitable: there are worse men than he is yet!'( Bronte, 276). But when Nelly directly addresses Heathcliff, she find no harm in reproaching or disdaining him 'Mr. Heathcliff,' said I, 'this is the talk of a madman; your wife, most likely, is convinced you are mad; and, for that reason, she has borne with you hitherto' ( Bronte, p. 243). Obviously, she rarely insults Heathcliff when he is absent, adorn if she does so it would be just in her thoughts"'Is he a ghoul or a vampire?' I mused (Bronte, p. 527). In doing so, she proves her role as wise and caring woman.

Additionally, On other occasions, Nelly does her best in order not to hurt her surroundings. We just need to see how she shuns reporting the exact harmful words of Edgar Linton to his sister "and all the way from the Grange I puzzled my brains how to put more heart into what he said, when I repeated it; and how to soften his refusal of even a few lines to console Isabella. (Bronte, p. 234-235). On the other hand, Lockwood presence in the novel is not of big weight. He is most of the time a narrate, a receiver of the story.

The Lockwood we encounter at the very beginning of the story is no longer the one we see towards the end the story. The circumstances in the new setting does not really meet his expectations: His "misanthropist's heaven" is no longer appreciate, and his " capital fellow" turns out to be a strange man. Given the roles assigned to both Nelly and Lockwood, it can be noticed that they both complement each other as narrators. Lockwood mystifies the reader through his presence as a stranger seeking some answers through misinterpreting events, distorting information, and mystifying the real story. As for Nelly, she occupies an explanatory role through correcting Lockwood's fallacies. In doing so, Nelly answers the reader's question by presenting some events in which she takes part. Moreover, the reader is put in a position where he can judge events as a common outsider. The Lockwood is bewildered by the hostile environment of the heights and so is the reader.

Time in Wuthering Heights is multilayered. There is the time of the story, and the way this time is represented through narration. The two principles narrators in Wuthering Heights reconstruct their stories through collecting the scattered pieces .In doing so, they reestablish the chronological order. The novel is introduced as a tale that is divided into two parts. Mr. Lockwood opens the narration then goes back into the past with Ellen Dean's narration.
The protagonist, , Heathcliff, is foreshadowed here without his name being mentioned at the very beginning. The narrator introduces the landlord whom we will later on know as Heathcliff, and whom the narrator " shall be troubled with". This last sentence is very significant in the way it marks a flashforward. The narrator is not giving us immediate details about the nature of the trouble with the landlord, but he only implies that he will have some troubles with Heathcliff. . After mentioning the time context of the story, Lockwood pauses to give us a short description of the place "This is certainly a beautiful country! In all England". This description interrupts the chronological continuity of the story. The description of Wuthering Heights is revealing in the way it reflects not only the dullness of the setting, but also the gloominess of its inhabitants. This fact will be apparent more with the lines describing Wuthering Heights:

\section{Wuthering Heights is the name of Mr. Heathcliff's dwelling. 'Wuthering' being a significant provincial adjective, descriptive of the atmospheric tumult to which its station is exposed in stormy weather. Pure, bracing ventilation they must have up there at all times indeed: one may guess the power of the north wind blowing over the edge, by the excessive slant of a few stunted firs at the end of the house; and by a range of gaunt thorns all stretching their limbs one way, as if craving alms of the sun (Bronte, p.4)}

This passage also marks a pause which describes Wuthering Heights. Once again, the duration of narrative space dominates the story time. We could notice that the narrator gives more importance to the fixed descriptive mood at the expense of the story's natural chronology.

\section{Mr. Heathcliff forms a singular contrast to his abode and style of living. He is a dark-skinned gipsy in aspect, in dress and manners a gentleman: that is, as much a gentleman as many a country squire: rather slovenly, perhaps, yet not looking amiss with his negligence, because he has an erect and handsome figure; and rather morose. (Bronte, p. 6)}

During his second visit to Wuthering Heights, Heathcliff comes across the diary of Catherine. The latter recounts :

'An awful Sunday,' commenced the paragraph beneath. 'I wish my father were back again. Hindley is a detestable substitute - his conduct to Heathcliff is atrocious - H. and I are going to rebel - we took our initiatory step this evening. All day had been flooding with rain; we could not go to church, so Joseph must needs get up a congregation in the garret; and, while Hindley and his wife basked downstairs before a comfortable fire - doing anything but reading their Bibles, I'll answer for it Heathcliff, myself, and the unhappy plough boy were commanded to take our prayer-books, and mount: we were ranged in a row, on a sack of corn, groaning and shivering, and hoping that Joseph would shiver too, so that he might give us a short homily for his own sake. 
A vain idea! The service lasted precisely three hours; and yet my brother had the face to exclaim, when he saw us descending, 'What, done already?' On Sunday evenings we used to be permitted to play, if we did not make much noise; now a mere titter is sufficient to send us into corners. (Bronte, p.31)

This diary represents the second shift in narrative time. It is a reference to the past of the protagonists. At the first glance, the readers are introduced to the past life of Heathcliff, his love affair with Cathy, the bad treatment he is subjected to by Hindley. This movements in time operates in the form of an flashback, a backward reference in time. This time shift purports to establish acausal link between the current state of Heathcliff and his past. It is a kind of psychological journey to the life of Heathcliff. The diary is supported by the handwriting of that chronicles the life of Cathrine, "a name repeated in all kinds of characters large and small 1- CATHERINE EARNSHAW, here and there varied to CATHERINE HEATHCLIFF, and then again to CATHERINE LINTON". (Bronte, p. 30)

If the protagonist turns out to be rude, greedy, violent and merciless it is, the readers would assume, because of the miserable and sad life he has led. The aforementioned backward reference in time also includes the change in the life of Heathcliff after the death of Mr. Earnshaw. Heathcliff is no longer teated as a member of the family, and Hindley would degrade him to a mere servant.

'How little did I dream that Hindley would ever make me cry so!' she wrote. 'My head aches, till I cannot keep it on the pillow; and still I can't give over. Poor Heathcliff! Hindley calls him a vagabond, and won't let him sit with us, nor eat with us anymore; and, he says, he and I must not play together, and threatens to turn him out of the house if we break his orders. He has been blaming our father (how dared he?) for treating H. too liberally; and swears he will reduce him to his right place (p. 34)

The unequal and inhumane treatment the protagonist gets from Hindley is apparent. Hindley turned him into a servant and threatened to throw him out. The analepsis explains the degradation and humiliation Heathcliff experiences as a result of Hindley's oppressive treatment. The separation of Catherine and Heathcliff seems to be the worst form of punishment for the children. These analepses are to illustrate the childhood abuse Heathcliff has to endure. They initiate in the reader a desire to justify the protagonist's inhospitable and wild manners in the initial chapters. Nevertheless, the details regarding Heathcliff's character are insufficient at the first phase because this information is limited to the two visits of the first narrator and the diary of Catherine about whom the reader does not know anything.
Banned from playing with Catherine, Heathcliff seems to experience the worst drama. This information seems to pave the way to the readers and the narrator to raise some important questions about the nature of the relationship between the different characters. Note here that when we mention the reader, the narrator Heathcliff is put on equal footing. He, just like the readers, is not fully acknowledgeable of what is going on, except some hints that are suggested by the diaries and the handwriting of Catherine. This technique adopted by Emily Bronte plays an important function in involving the reader with Mr. Lockwood. In his article on the psychology of Lockwood dream in the Heights, Steven Joyce writes:

His observations and experience make credible the claim that the room is haunted. Moreover, it allows Bronte $\square$ to lay the groundwork for the subsequent tale of dark gothic romance. Animated, haunted by the strange fragments written in the margins of an old bible, fragments of a time that need only a consciousness to revive itself (and here redolent of Odysseus in Hades reviving the memories of those with whom he wishes to speak), Lockwood provides the blood-rich consciousness that allows the room to come to life, not entirely without vampiric and messianic overtones. (2008,p. 4)

Puzzled by the information he has been exposed to in addition to the ghost of Catherine, Lockwood resorts to Nelly Dean to tell him about the story of the family.'Well, Mrs. Dean, it will be a charitable deed to tell me something of my neighbours: I feel I shall not rest if I go to bed; so be good enough to sit and chat an hour.'(p. 54). The the beginning of Mrs. Dean's narration narration constitutes the third movement in narrative time. Nelly commences by recounting about the fist arrival of Heathcliff, and how he triggers a feeling of disappointment among the children who have been expecting their gifts, and to their astonishment their father brings "a dirty, ragged, black-haired child" from the streets of Liverpool. Nelly continues relating about the Heathcliff's childhood, his first contact with the children.

They entirely refused to have it in bed with them, or even in their room; and I had no more sense, so I put it on the landing ahe stairs, hoping it might he gone on the morrow. By chance, or else attracted by hearing his voice, it crept to $\mathrm{Mr}$. Earnshaw's door, and there he found it on quitting his chamber. Inquiries were made as to how it got there; I was obliged to confess, and in recompense for my cowardice and inhumanity was sent out of the house. (P. 58).

This flashback or anallpses introduces the main story of the protagonists, and comprises chapters four, five and six. The Story of Heathcliff's 's arrival to Wuthering Heights is the general frame upon which the story is established. The embedded story of Nelly Dean plays an explanatory causal role by linking the present to the past. 
Interestingly, the second story that is narrated by Nelly, though is is meant to account for what it is going on, gains more attention from the readers. It is a full-fledged story. We shall elaborate more on the notion of embedded narration in the upcoming chapter. Heathcliff is introduced to the family as an anonymous person. The family members seem astonished over the master's bringing a stranger at home. Interestingly, it is through their reaction toward the new boy that we manage to get an idea on the members of the family. Hindely grows vengeful toward Heathcliff, and Cathy manages to get closer to him. Mr. Earnshaw's love for Heathcliff was apparent, and even Heathcliff employs this love for his own benefit:

You must exchange horses with me: I don't like mine; and if you won't I shall tell your father of the three thrashings you've given me this week, and show him my arm, which is black to the shoulder.(p.61)

Heathcliff is now aware of his strength as the spoiled child of Mr. Earnshaw. Note how he blackmails Hindley to exchange horses or tell his master about the way he has misstated him. However, Heathcliff loses this advantage as Mr. Earnshaw dies. This part also chronicles the changes Heathcliff he experiences over the death of his master, Mr. Earnshaw. Hindley starts to mistreat Heathcliff openly:

He drove him from their company to the servants, deprived him of the instructions of the curate, and insisted that he should labour out of doors instead; compelling him to do so as hard as any other lad on the farm (p. 71)

Hindley drives Heathcliff out of the Heights and no longer consider him a member of the family. At this important point, the picture becomes clearer for the readers. To put it clearly, the diary of Catherine makes sense now, and the reader gains a full understanding of the fragmented and scattered instances Catherine Alludes to in her diaries. In this regard, Citing C.P Sanger, Melvin Watson states that:

C. P. Sanger's The Structure of Wuthering Heights deals entirely with technical aspects of the novel, but it is vital for our understanding of the maturity of legal knowledge shown there in and the care with which the chronology was planned. Although on the surface the time elements chaotic and confused, every major event can be accurately dated. Its total effect its coherence and unity, its form, and its presiding significance are what Lascelles Abercrombie is intent on showing. (P. 261).

Emily Bronte manages to establish an extraordinary link between events and records that operates within different time, yet that gives the story more embellishment and excitement. This is reminiscent of detective stories in which some pieces of information are introduced in moments where they seem useless, yet there significance emerges in the course of events, something that is similar to card matching games where the players are to find the suitable place of each square.
Regardless of the violence and marginalization that Heathcliff is subjected to, he still holds on his love for Catherine. The two protagonists creates their own world of the moors. A world that is free from the constraints and the tyranny of the other members of the Heights.

Heathcliff had gone to loose the beast, and shift it to his own stall; he was passing behind it, when Hindley finished his speech by knocking him under its feet, and without stopping to examine whether his hopes were fulfilled, ran away as fast as he could. I was surprised to witness how coolly the child gathered himself up, and went on with his intention; exchanging saddles and all, and then sitting down on a bundle of hay to overcome the qualm which the violent blow occasioned, before he entered the house. I persuaded him easily to let me lay the blame of his bruises on the horse: he minded little what tale was told since he had what he wanted. He complained so seldom, indeed, of such stirs as these, that I really thought him not vindictive: I was deceived completely, as you will hear.(p. 62)

It was for God to punish wicked people; we should learn to forgive". "No God won't have the satisfaction that I shall," he returned. "I only wish I knew the best way! Let me alone, and I'll plan it out: while I'm thinking of that I don't feel pain" ( $p$. 95).

The next period referred to in Nelly narration is very decisive. Along with the maltreatment Heathcliff is exposed to, he has to undergo the worst case scenario of losing his beloved Catherine. During her stay in Thrushcross Grange, Catherine grows more aware of her status as a more refined lady. Having shown that, the author implicitly anticipates the growing motives of Heathcliff to take revenge of the people who have caused him suffering, misery, and above all usurped him of his reason d'être, Catherine. However how revengeful he becomes, Heathcliff cannot hate Catherine , "The notion of ENVYING Catherine was incomprehensible to him, but the notion of grieving her he understood clearly enough" 87. He feels that he has lost her physically, culturally, and emotionally; she adopts more cultivated and refined manners, hence, Heathcliff is seen as a part of the old uncivilized manner, Nelly narrates:

"Cathy, catching a glimpse of her friend in his concealment, flew to embrace him; she bestowed seven or eight kisses on his cheek within the second, and then stopped, and drawing back, burst into a laugh, exclaiming, 'Why, how very black and cross you look! and how - how funny and grim! But that's because I'm used to Edgar and Isabella Linton. Well, Heathcliff, have you forgotten me?

She had some reason to put the question, for shame and pride threw double gloom over his countenance, and kept him immovable."( p. 83) 
Whereas Heathcliff seems to be aware of the changes she has undergone at a first glance:

'You needn't have touched me!' he answered, following her eye and snatching away his hand. 'I shall be as dirty as I please: and I like to be dirty, and I will be dirty. '(p.84)

This changes constitutes an upheaval in their relationship, it signals the shaking of their relationship and their idealistic moments in the moors. Heathcliff feels alone after Catherine abandons him and chooses to be closer to the Lintons, the inhabitants of Thrushcross Grange.

The role of anachronizes is significant in shaping the reader's measurement of events and characters behaviors. In Wuthering Heights most of the shifts in narrative time mark some analpses. The latter give an account on the history of a character as well as his psychological, emotional and intellectual backgrounds and records. Hence, every action should be traced back to the character's history. As stated before, Heathcliff represents a case in this point. The protagonist actions and misconducts stem from his history, the violence and absence of tenderness he has been subjected to since the Death of Mr Earnshaw. To some extent the reactions of Heathcliff seem natural. Nelly Narrates:

He had reached the age of sixteen then, I think, and without having bad features, or being deficient in intellect, he contrived to convey an impression of inward and outward repulsiveness that his present aspect retains no traces of. In the first place, he had by that time lost the benefit of his early education: continual hard work, begun soon and concluded late, had extinguished any curiosity he once possessed in pursuit of knowledge, and any love for books or learning. His childhood sense of superiority, instilled into him by the favors of old Mr. Earnshaw, was faded away (p. 106).

The character of Heathcliff is reminiscent of some common protagonists who have been considered as inferior among their surroundings, and who have reacted to this through a pursuit of wealth and power. For example, in The Great Gatsby, Jay Gatsby reappears as a wealthy businessman in an attempt to regain his beloved Daisy. Likewise, Heathcliff takes the same direction. After he has been usurped of all the privileges in Wuthering Heights, including Catherine's love, Heathcliff leaves the house in quest of a new identity, an identity by which he can be seen as a powerful man, hence, pays back his enemies.

After some years of absence, Heathcliff returns home a wealthy man. The part from chapter ten to sixteen, narrated by Nelly, chronicles the sudden return of Heathcliff and its destructive effect on the two families: the Eanshaws and the Lintons. It should be noted here that Nelly Dean has already stated that she ignores how Heathcliff gained his money(p. 54). In doing so, Nelly proves reliable. And even if she made some predictions as to how he gained his money, the reader would assume that she is being subjective.
Many indications (prolepses) depicted in this part foreshadows Heathcliff's priority to take revenge of his " enemies". This anticipations by Nelly raises the readers suspicion toward Heathcliff pretentious and fake manners. He is growing more and more hypocrite in an attempt to gain the admiration of the others, but deep inside he prepares himself for revenge. In many instances Nelly refers to that, for instance:

"Mr. Earnshaw invited HIM! and HE called on Mr. Earnshaw! I pondered this sentence painfully, after he was gone. Is he turning out a bit of a hypocrite, and coming into the country to work mischief under a cloak? I mused: I had a presentiment in the bottom of my heart that he had better have remained away".(p.154)

This part marks a prolepses in the sense that Nelly anticipates Heathcliff's mischievous plan to destroy Hindley. Nelly is aware of Heathcliff's vindictive intentions.The word "presentiments" implies an intuitive feeling about a future action. Furthermore, Heathcliff introduces himself to the Lintons. As a part of his plan to destroy them and gain Catherine back, he attempts to get closer to the family. The presence of Heathcliff among the Earnshaws and the Lintons triggers many conflicts. Isabella gets more jealous and harsh toward her sister in law whom she considers her rival. This conversation shows that their relationship takes a different way:

'You are a dog in the manger, Cathy, and desire no one to be loved but yourself!'

'You are an impertinent little monkey!' exclaimed Mrs. Linton, in surprise. (P.162)

Catherine also hints at the miserable situation the family is getting through with the presence of Heathcliff around:

Edgar is restored from the ill-temper he gave way to at your coming; I begin to be secure and tranquil; and you, restless to know us at peace, appear resolved on exciting a quarrel. Quarrel with Edgar, if you please, Heathcliff, and deceive his sister: you'll hit on exactly the most efficient method of revenging yourself on me.' (P.180)

Needless to say, the narrative time in Wuthering Heights is very complicated. The shifts in narrative time are on constant basis. The readers find themselves obliged to concentrate more to keep trace of the chronological order of events. This does not mean that this methods adopted by the author makes the novel less enjoyable, on the contrary it involves the reader and makes him asks many question, make predictions, and links some events to others. Additionally, it goes without saying that anticipating an action in the form of a prolepses triggers the readers curiosity. The latter keeps verifying if the predicted action would take place or not. 
For example, When Heathcliff asks Nelly to arrange a meeting between him and Catherine, the latter refuses, and Heathcliff insisting on seeing her regardless of the circumstances: "I must exact a promise from you, that you'll get me an interview with her: consent, or refuse, I will see her! What do you say?" 237. Ultimately, Heathcliff manages to meet Catherine.

The next phase of the narrative time chronicles about eighteen years. Heathcliff's nonstop mourning of Catherine transforms him into an unsociable and monstrous character. This includes from chapter seventeen until chapter thirty. Many people overlook this point of view when thinking about a book. However, point of view gives the reader a perspective about the story, and it can change the entire tone of the story depending on the narrator. In Wuthering Heights, there are many different points of views from different characters. As a result, the reader is able to really immerse into the great novel that is Wuthering Heights.

In Wuthering Heights, most events are written based on Nelly's point of view. Nelly is telling the entire story to Lockwood, who also has a bit of a narration. Nelly is not an omniscient narrator; sometimes she isn't there for certain events that take place. For example, when Heathcliff goes off by himself to the entire night and returns in a wild mood, Nelly wasn't there for the event. Heathcliff simply tells Nelly a vague description, and the reader must infer what happened that night. However, Nelly does narrate the story in a third person point of view. The opinions and thoughts of all the characters are in the story, but they are simply what Nelly thinks they felt in that very moment.

Lockwood is another narrator. When he narrates the story, he is writing in his diary. Because of this, when Lockwood narrates, it is in first person point of view. We are still able to see what is going on in the plot, because Lockwood notes everything in his diary. When Lockwood narrates, we are able to view how the inhabitants of Wuthering Heights act from the outside looking in. For example, when Lockwood has dinner with Heathcliff, Hareton and others at Wuthering Heights we are able to see how Lockwood views these people, and we get a sense of how estranged the family really is. Since it is his diary, we can see how Lockwood feels when he witnesses the events going on. He later dreams about how life would be if Young Cathy were to marry him, and as a result we are able to think about different possible endings, and how the themes would be affected as a result.

There was a reason why Emily Brontë chose to have two different points of views, and why none of the narrators were the main characters. Since we have a third person point of view and a first person point of view we are able to feel the events more deeply. If the entire book were told in Heathcliff's point of view, the reader would have different feelings.
We would view Edgar as a vicious monster who stole Catherine away from the best thing that ever happened to her. If the entire book were told in Catherine's point of view, the book would be much shorter than its actual length, seeing as how Catherine dies in the midpoint of the book. Nelly gives the reader the entire perspective of all the characters and most of the events. Although she has a bias, such as viewing Catherine as a brat, this helps the reader along with why characters might have acted certain ways.

Seeing as how Nelly witnesses almost everything that happens in the book, the theme statement that love, no matter what form, will go on for eternity really comes true. Nelly sees everything bad that happens to the characters, all the sufferings, tribulations and challenges that they face. Because she sticks through it until the end she is able to see that Heathcliff and Catherine's love really did last. When Heathcliff was telling Nelly that Catherine's body hasn't decomposed yet, we can see that their love really did last for an eternity. Also, the theme statement that the death of a loved one can result in paranoia comes true with the narration. Nelly obviously sees Heathcliff become a man filled with revenge, and she witnesses Heathcliff being haunted by Catherine's spirit. When she gives us a third person perspective, it really brings out the paranoia that Heathcliff is going through.

Lockwood's perspective into the story makes the statement that love doesn't conquer all comes true, as well. He sees that Heathcliff is a cold man who treats people poorly, and we can see that love doesn't conquer all. If it did, then Heathcliff would be with Catherine and he wouldn't be as bitter as Lockwood really sees him as. Also, when he first visits Wuthering Heights and meets most of the characters, Young Cathy is a harsh young lady. If love really did conquer, then she would be able to be with Linton. They were forced together by Heathcliff, and if their love was able to fight back the oppression then they would be happily married. But Lockwood sees that Young Cathy is now rude, and through this we gain perspective into the themes.

\section{Works Cited:}

1. Ahmed. A .H 2017 "The Pragmatics of Apology Speech Act Behaviour in Iraqi Arabic and English. Front Cover. De Montfort University

2.Barthes, Roland ([1966] 1975) "An Introduction to the Analysis of Narrative." New Literary History 6, 237-72.

\section{Booth, Wayne C. ([1961] 1983). The Rhetoric of Fiction. Chicago: U of Chicago}

4. Bremond (C.), Logique du récit, Seuil, 1973, p. 11-47.

5. Brontë, Emily. Wuthering Heights. Mineola, N.Y.: Dover Publications, 1996 
6. Edmiston, William F. "Focalization and the First-Person Narrator: A Revision of the Theory." Poetics Today 10.4 (1989)

7. Genette, Gérard ([1972] 1980). Narrative Discourse: An Essay in Method. Ithaca: Cornell UP.

8. Greimas, Algirdas Julien ([1966] 1983). Structural Semantics: An Attempt at a Method. Lincoln: Nebraska UP.

9.Joyce Steven Romancing Freud--the Peculiar Dreams of Mr. Lockwood in Bronte's Wuthering Heights. The Ohio State University.

10. Mansfield Campus 1680 University Drive Mansfield, Ohio 44906 USA

\section{Lévi-Strauss, Claude ([1958] 1963). Structural Anthropology. New York: Basic Books}

12. Lévi-Strauss (C.), La structure et la forme est accessible dans le t. II de son Anthropologie structurale, Plon, 1973.

13. Lodge, David. The Art of Fiction. London: Penguin Books, 1992

14. Mélétinski (E.), L'étude structurale et typologie du conte, 202-254. de l'édition « Points » de la Morphologie du conte
15. Prince, Gerald (1990). "On Narratology (Past, Present, Future).” French Literature Series 17, 1-14.

16. Propp, Vladimir ([1928] 1958). Morphology of the Folktale. Bloomington: Indiana UP

17. Propp, Morphologie du conte, Seuil, coll. « Points », $\mathrm{n}^{\circ}$ 121970.

18. Ricardou (J.), Le nouveau roman, Seuil, coll. « Ecrivains de toujours », $n^{\circ} 921973$, p. 26-47 et 139-140.

19. Todorov (T.), Les catégories du récit littéraire, Communications, $n^{\circ} 81966$.

20. Willams, Anne . Natural Supernaturalism in Wuthering Heights. Studies in Philology, Vol. 82, No. 1 (Winter, 1985), pp. 104-127

Citation: *Mr. Omar Ezzaoua “On Double Narration in Wuthering Heights". American Research Journal of English and Literature, Volume 7 ,Issue No. 1, 2021, pp. 1-14.

Copyright (C) 2021 Mr. Omar Ezzaoua. This is an open access article distributed under the Creative Commons Attribution License, which permits unrestricted use, distribution, and reproduction in any medium, provided the original work is properly cited. 